\title{
Identification of four genes as novel susceptibility loci for early-onset type 2 diabetes mellitus, metabolic syndrome, or hyperuricemia
}

\author{
YOSHIJI YAMADA ${ }^{1,2}$, KIMIHIKO KATO ${ }^{1,3}$, MITSUTOSHI OGURI ${ }^{1,4}$, HIDEKI HORIBE $^{5}$, \\ TETSUO FUJIMAKI $^{6}$, YOSHIKI YASUKOCHI ${ }^{1,2}$, ICHIRO TAKEUCHI ${ }^{2,7,8}$ and JUN SAKUMA ${ }^{2,8,9}$
}

\begin{abstract}
${ }^{1}$ Department of Human Functional Genomics, Advanced Science Research Promotion Center, Mie University, Tsu, Mie 514-8507; ${ }^{2}$ CREST, Japan Science and Technology Agency, Kawaguchi, Saitama 332-0012; ${ }^{3}$ Department of Internal Medicine, Meitoh Hospital, Nagoya, Aichi 465-0025; ${ }^{4}$ Department of Cardiology, Kasugai Municipal Hospital, Kasugai, Aichi 486-8510; ${ }^{5}$ Department of Cardiovascular Medicine, Gifu Prefectural Tajimi Hospital, Tajimi, Gifu 507-8522; ${ }^{6}$ Department of Cardiovascular Medicine, Northern Mie Medical Center Inabe General Hospital, Inabe, Mie 511-0428; ${ }^{7}$ Department of Computer Science, Nagoya Institute of Technology, Nagoya, Aichi 466-8555;

${ }^{8}$ RIKEN Center for Advanced Intelligence Project, Tokyo 103-0027; ${ }^{9}$ Computer Science Department, College of Information Science, University of Tsukuba, Tsukuba, Ibaraki 305-8573, Japan
\end{abstract}

Received April 28, 2018; Accepted May 21, 2018

DOI: $10.3892 /$ br.2018.1105

\begin{abstract}
Given that early-onset type 2 diabetes mellitus (T2DM), metabolic syndrome (MetS), and hyperuricemia have been shown to have strong genetic components, the statistical power of a genetic association study may be increased by focusing on early-onset subjects with these conditions. Although genome-wide association studies have identified various genes and loci significantly associated with T2DM, MetS, and hyperuricemia, genetic variants that contribute to predisposition to these conditions in Japanese subjects remain to be identified definitively. We performed exome-wide association studies (EWASs) for early-onset T2DM, MetS, or hyperuricemia to identify genetic variants that confer susceptibility to these conditions. A total of 8,102 individuals aged $\leq 65$ years were enrolled in the present study. The EWAS for T2DM was performed with 7,407 subjects (1,696 cases, 5,711 controls), that for MetS with 4,215 subjects (2,296 cases, 1,919 controls), and that for hyperuricemia with 7,919 subjects (1,365 cases, 6,554 controls). Single nucleotide polymorphisms (SNPs) were genotyped with Illumina Human Exome-12 DNA Analysis BeadChip or Infinium Exome-24 BeadChip arrays. The relationship of allele frequencies for $31,210,31,521$, or
\end{abstract}

Correspondence to: Professor Yoshiji Yamada, Department of Human Functional Genomics, Advanced Science Research Promotion Center, Mie University, 1577 Kurima-machiya, Tsu, Mie 514-8507, Japan

E-mail: yamada@gene.mie-u.ac.jp

Key words: diabetes mellitus, metabolic syndrome, hyperuricemia, genetics, exome-wide association study
31,142 SNPs that passed quality control for T2DM, MetS, or hyperuricemia, respectively, was examined with Fisher's exact test. To compensate for multiple comparisons of genotypes with T2DM, MetS, or hyperuricemia, we applied Bonferroni's correction for statistical significance of association. The EWAS of allele frequencies revealed that four, six, or nine SNPs were significantly associated with T2DM $\left(\mathrm{P}<1.60 \times 10^{-6}\right)$, MetS $\left(\mathrm{P}<1.59 \times 10^{-6}\right)$, or hyperuricemia $\left(\mathrm{P}<1.61 \times 10^{-6}\right)$, respectively. Multivariable logistic regression analysis with adjustment for age and sex revealed that three, six, or nine SNPs were significantly related to T2DM $(\mathrm{P}<0.0031)$, MetS $(\mathrm{P}<0.0021)$, or hyperuricemia $(\mathrm{P}<0.0014)$. After examination of the association of identified SNPs to T2DM-, MetS-, or hyperuricemia-related traits, linkage disequilibrium of the SNPs, and results of previous genome-wide association studies, newly identified $Z N F 860$ and $O R 4 F 6$ were the susceptibility loci for T2DM, OR52E4 and OR4F6 for MetS, and HERPUD2 for hyperuricemia. Given that OR4F6 was significantly associated with both T2DM and MetS, we newly identified four genes (ZNF860, OR4F6, OR52E4, HERPUD2) that confer susceptibility to early-onset T2DM, MetS, or hyperuricemia. Determination of genotypes for the SNPs in these genes may prove informative for assessment of the genetic risk for T2DM, MetS, or hyperuricemia.

\section{Introduction}

Diabetes mellitus (DM) has reached epidemic proportions and affects more than 382 million individuals worldwide (1): The number of patients with DM is expected to increase beyond 592 million individuals by 2035 (1). Approximately 90 to $95 \%$ of individuals with DM have type 2 DM (T2DM), the characteristics of which can range from predominant insulin deficiency with relatively minor insulin resistance to 
predominant insulin resistance with relatively minor insulin deficiency (2). T2DM is a major cause of nephropathy, retinopathy, and neuropathy as well as cardiovascular disease and stroke $(3,4)$. Although obesity resulting from a sedentary lifestyle and overeating is an important risk factor for T2DM, genetic components are involved in the pathogenesis of this condition, given that a positive family history confers a 2.4-fold increased risk for T2DM (5). The heritability of T2DM has been estimated to be 50 to $60 \%$ (6).

Genome-wide association studies (GWASs) and meta-analyses have identified $>120$ susceptibility loci for T2DM (7) in individuals of European (8-13) or African (14) ancestry, in East Asians (15), or in multiple ethnic groups $(16,17)$. Among Japanese, GWASs have identified KCNQ1, UBE2E2, and $C 2 C D 4 A-B$ (18-20) as susceptibility genes for T2DM, and a recent meta-analysis identified an additional seven susceptibility loci for this condition (21). Genetic variants that contribute to predisposition to T2DM in Japanese subjects, however, remain to be identified definitively.

Metabolic syndrome (MetS) is a cluster of metabolic traits including abdominal obesity, an increased serum triglycerides, a decreased serum high-density lipoprotein (HDL) cholesterol, high blood pressure (BP), and an increased fasting plasma glucose (FPG) level (22). MetS is a risk factor for atherosclerotic cardiovascular disease, DM (23), and cancer (24). The etiology of MetS is highly complex, with both genetic and environmental factors being thought to play important roles. The heritability of MetS has been estimated to be approximately $50 \%$ (25) and traits of this syndrome to be 28 to $48 \%$ (26).

GWASs have suggested various loci or genes involved in predisposition to MetS or to traits of this syndrome in individuals of European (27,28) or African (29) ancestry or in Asian Indians (30) or Chinese individuals (31). However, genetic variants that contribute to predisposition to MetS in Japanese individuals remain to be identified definitively.

Circulating uric acid levels are regulated by multiple renal transporters by mediating the excretion or reabsorption of uric acid in the proximal kidney tubules (32). Hyperuricemia is an important risk factor for gout, a common inflammatory arthritis (33), as well as for cardiovascular disease (34) and cancer (35). The heritability of the serum concentration of uric acid has been estimated to be $40 \%$ (36), suggesting that genetic variants contribute to regulation of the serum uric acid level by influencing uric acid synthesis, excretion, or reabsorption $(36,37)$.

GWASs have identified single nucleotide polymorphisms (SNPs) significantly associated with the serum uric acid concentration or the prevalence of gout (38-45). A large-scale GWAS in European ancestry populations identified 28 loci that influence the serum concentration of uric acid (46). Although several SNPs have been shown to be associated with gout in Japanese $(47,48)$, genetic variants that contribute to predisposition to hyperuricemia in Japanese remain to be identified definitively.

In a family study of T2DM, a heritability of T2DM was higher in early-onset than late-onset individuals (6). These observations indicate that early-onset T2DM has a strong genetic component $(6,49)$. Similar to T2DM, early-onset forms of MetS $(50,51)$, hyperuricemia, and gout $(52,53)$ have been shown to have strong genetic components. Given that genetic contribution may be greater in early-onset forms of T2DM,
MetS, and hyperuricemia than in late-onset forms, statistical power of the genetic association study may be increased by focusing on early-onset subjects with these conditions.

In the present study, we performed exome-wide association studies (EWASs) with the use of human exome array-based genotyping methods to identify genetic variants that confer susceptibility to early-onset T2DM, MetS, or hyperuricemia in Japanese patients. To increase the statistical power of EWASs, early-onset subjects were examined.

\section{Materials and methods}

Study subjects. In previous studies, the median age of subjects with T2DM (54), MetS (55), or hyperuricemia (56) was 68,64, or 62 years, respectively. We thus defined subjects aged $\leq 65$ years as early-onset cases in the present study. A total of 8,102 individuals aged $\leq 65$ years were examined. The subjects were recruited from individuals either who visited outpatient clinics of or were admitted to participating hospitals in Japan (Gifu Prefectural Tajimi Hospital, Tajimi; Gifu Prefectural General Medical Center, Gifu; Japanese Red Cross Nagoya First Hospital, Nagoya; Northern Mie Medical Center Inabe General Hospital, Inabe; Hirosaki University Hospital and Hirosaki Stroke and Rehabilitation Center, Hirosaki) because of various symptoms or for an annual health checkup between October 2002 and March 2014; or who were community-dwelling individuals recruited to a population-based cohort study in Inabe between March 2010 and september 2014 (57).

T2DM was defined according to the criteria of the World Health Organization as described previously $(2,58,59)$. Subjects with T2DM had an FPG level of $\geq 6.93 \mathrm{mmol} / 1$ (126 mg/dl) or a blood hemoglobin $A_{1 c}$ content of $\geq 6.5 \%$ or were taking antidiabetes medication. Individuals with T1DM, maturity-onset diabetes of the young, DM associated with mitochondrial diseases or single-gene disorders, pancreatic diseases, or other metabolic or endocrinologic diseases were excluded from the study. Those taking medications that may cause secondary DM were also excluded. The control subjects had an FPG level of $<6.05 \mathrm{mmol} / 1(110 \mathrm{mg} / \mathrm{dl})$, a blood hemoglobin $\mathrm{A}_{1 \mathrm{c}}$ content of $<6.2 \%$, and no history of DM or of having taken antidiabetes medication. We thus examined 1,696 subjects with T2DM and 5,711 controls.

Diagnosis of MetS was based on a modified version of the definition proposed by the International Diabetes Federation Task Force on Epidemiology and Prevention; National Heart, Lung, and Blood Institute; American Heart Association; World Heart Federation; International Atherosclerosis Society; and International Association for the Study of Obesity (22). We used cut-off values for waist circumference of $\geq 90 \mathrm{~cm}$ in men or $\geq 80 \mathrm{~cm}$ in women on the basis of a recommendation of the International Diabetes Association (22). A total of 2,296 subjects with MetS thus had three or more of the following five components: i) A waist circumference of $\geq 90 \mathrm{~cm}$ for men or $\geq 80 \mathrm{~cm}$ for women; ii) a serum triglyceride concentration of $\geq 1.65 \mathrm{mmol} / 1$ (150 mg/dl) or drug treatment for elevated triglycerides; iii) a serum HDL-cholesterol concentration of $<1.04 \mathrm{mmol} / \mathrm{l}(40 \mathrm{mg} / \mathrm{dl})$ for men or $<1.30 \mathrm{mmol} / \mathrm{l}(50 \mathrm{mg} / \mathrm{dl})$ for women; iv) a systolic BP of $\geq 130 \mathrm{mmHg}$, diastolic BP of $\geq 85 \mathrm{mmHg}$, or drug treatment for hypertension; and v) an FPG level of $\geq 5.50 \mathrm{mmol} / \mathrm{l}(100 \mathrm{mg} / \mathrm{dl})$ or drug treatment 
Table I. Characteristics of subjects with type 2 diabetes mellitus and control individuals.

\begin{tabular}{|c|c|c|c|}
\hline Characteristic & Control & Type 2 diabetes mellitus & P-value \\
\hline No. of subjects & 5,711 & 1,696 & \\
\hline Age (years) & $50.4 \pm 10.2$ & $56.3 \pm 7.2$ & $<0.0001$ \\
\hline $\operatorname{Sex}(\operatorname{men} /$ women, \%) & $52.1 / 47.9$ & $76.2 / 23.8$ & $<0.0001$ \\
\hline Smoking (\%) & 40.0 & 47.5 & 0.0105 \\
\hline Obesity (\%) & 28.1 & 45.2 & $<0.0001$ \\
\hline Body mass index $\left(\mathrm{kg} / \mathrm{m}^{2}\right)$ & $22.9 \pm 3.3$ & $24.7 \pm 3.9$ & $<0.0001$ \\
\hline Hypertension (\%) & 32.0 & 71.0 & $<0.0001$ \\
\hline Systolic BP (mmHg) & $122 \pm 20$ & $140 \pm 27$ & $<0.0001$ \\
\hline Diastolic BP (mmHg) & $75 \pm 13$ & $80 \pm 15$ & $<0.0001$ \\
\hline Fasting plasma glucose $(\mathrm{mmol} / \mathrm{l})$ & $5.17 \pm 0.48$ & $8.95 \pm 3.77$ & $<0.0001$ \\
\hline Blood hemoglobin $\mathrm{A}_{1 \mathrm{c}}(\%)$ & $5.48 \pm 0.31$ & $7.33 \pm 1.87$ & $<0.0001$ \\
\hline Dyslipidemia (\%) & 54.4 & 80.2 & $<0.0001$ \\
\hline Serum triglycerides $(\mathrm{mmol} / \mathrm{l})$ & $1.29 \pm 0.89$ & $1.82 \pm 1.47$ & $<0.0001$ \\
\hline Serum HDL-cholesterol (mmol/l) & $1.62 \pm 0.46$ & $1.32 \pm 0.43$ & $<0.0001$ \\
\hline Serum LDL-cholesterol (mmol/l) & $3.14 \pm 0.82$ & $3.15 \pm 0.97$ & 0.8052 \\
\hline Chronic kidney disease (\%) & 10.9 & 26.8 & $<0.0001$ \\
\hline Serum creatinine $(\mu \mathrm{mol} / \mathrm{l})$ & $70.4 \pm 63.1$ & $93.1 \pm 122.6$ & $<0.0001$ \\
\hline eGFR (ml min $\left.{ }^{-1} 1.73 \mathrm{~m}^{-2}\right)$ & $78.4 \pm 18.9$ & $73.2 \pm 24.6$ & $<0.0001$ \\
\hline Hyperuricemia (\%) & 14.5 & 22.9 & $<0.0001$ \\
\hline Serum uric acid $(\mu \mathrm{mol} / \mathrm{l})$ & $321 \pm 90$ & $340 \pm 102$ & $<0.0001$ \\
\hline
\end{tabular}

Quantitative data are means \pm standard deviations and were compared between subjects with type 2 diabetes mellitus and controls with the unpaired Student's t-test. Categorical data were compared between two groups with Pearson's Chi-square test. Based on Bonferroni's correction, a P-value of $<0.0026(0.05 / 19)$ was considered statistically significant. Definitions of diseases: Obesity, body mass index of $\geq 25 \mathrm{~kg} / \mathrm{m}^{2}$; hypertension, systolic BP of $\geq 140 \mathrm{mmHg}$, diastolic BP of $\geq 90 \mathrm{mmHg}$, or taking of anti-hypertensive medication; dyslipidemia, serum triglyceride concentration of $\geq 1.65 \mathrm{mmol} / \mathrm{l}$, serum HDL-cholesterol concentration of $<1.04 \mathrm{mmol} / \mathrm{l}$, serum LDL-cholesterol concentration of $\geq 3.64 \mathrm{mmol} / 1$, or taking of anti-dyslipidemic medication; chronic kidney disease, eGFR of $<60 \mathrm{ml} \mathrm{min}^{-1} 1.73 \mathrm{~m}^{-2}$; hyperuricemia, serum uric acid concentration of $>416 \mu \mathrm{mol} / \mathrm{l}$ or taking of uric acid-lowering medication. BP, blood pressure; HDL, high density lipoprotein; LDL, low density lipoprotein; eGFR, estimated glomerular filtration rate.

for elevated glucose. History of obesity, dyslipidemia, hypertension, or DM was evaluated with a detailed questionnaire. The control subjects comprised 1,919 individuals who had none of the five traits of MetS.

Hyperuricemia was defined as a serum uric acid concentration of $>416 \mu \mathrm{mol} / 1$ ( $7 \mathrm{mg} / \mathrm{dl})$ or taking of uric acid-lowering medication. Individuals taking drugs that potentially caused secondary hyperuricemia were excluded. The control individuals for the study of hyperuricemia had a serum uric acid concentration of $\leq 416 \mu \mathrm{mol} / 1$ and had no history of hyperuricemia or gout or of taking uric acid-lowering medication. Thus, we examined 1,365 subjects with hyperuricemia and 6,554 controls.

The 1,040 subjects with both T2DM and MetS as well as 1,884 controls overlapped between the corresponding studies, as did the 375 subjects with both T2DM and hyperuricemia and 4,809 controls as well as the 628 subjects with both MetS and hyperuricemia and 1,771 controls.

EWASs. Venous blood $(5-7 \mathrm{ml})$ was collected into tubes containing $50 \mathrm{mmol} / \mathrm{l}$ ethylenediaminetetraacetic acid (disodium salt), peripheral blood leukocytes were isolated, and genomic DNA was extracted from these cells either with the use of a kit (Genomix from Talent Srl, Trieste, Italy or SMITEST EX-R\&D from Medical \& Biological Laboratories, Co., Ltd., Nagoya, Japan).

The EWAS for T2DM, MetS, or hyperuricemia included 7,407 individuals (1,696 subjects with T2DM, 5,711 controls), 4,215 individuals (2,296 subjects with MetS, 1,919 controls), or 7,919 individuals (1,365 subjects with hyperuricemia, 6,554 controls), respectively. The EWASs were performed with the use of a Human Exome-12 v1.2 DNA Analysis BeadChip or Infinium Exome-24 v1.0 BeadChip (Illumina, San Diego, CA, USA). These exome arrays include putative functional exonic variants selected from $\sim 12,000$ individual exome and whole-genome sequences. The exonic content consisted of 244,000 SNPs from diverse populations, including European, African, Chinese, and Hispanic individuals (60). SNPs contained in only one exome array ( $\sim 2.6 \%$ of all SNPs) were excluded from analysis. We performed quality control (61) as follows: i) Genotyping data with a call rate of $<97 \%$ were discarded, with the mean call rate for the remaining data being 99.9\%. ii) Sex specification was checked for all the samples, and those for which sex phenotype in the clinical records was inconsistent with genetic sex were discarded. iii) Duplicated samples and cryptic relatedness were checked by calculation 
Table II. Characteristics of subjects with metabolic syndrome and control individuals.

\begin{tabular}{|c|c|c|c|}
\hline Characteristic & Control & Metabolic syndrome & $\mathrm{P}$-value \\
\hline No. of subjects & 1,919 & 2,296 & \\
\hline Age (years) & $47.0 \pm 10.7$ & $55.0 \pm 8.0$ & $<0.0001$ \\
\hline Sex (men/women, \%) & $42.3 / 57.7$ & $67.9 / 32.1$ & $<0.0001$ \\
\hline Smoking (\%) & 35.2 & 46.1 & $<0.0001$ \\
\hline Waist circumference $(\mathrm{cm})$ & $74.0 \pm 6.0$ & $88.3 \pm 9.0$ & $<0.0001$ \\
\hline Body mass index $\left(\mathrm{kg} / \mathrm{m}^{2}\right)$ & $20.8 \pm 2.2$ & $26.0 \pm 3.7$ & $<0.0001$ \\
\hline Systolic BP (mmHg) & $109 \pm 11$ & $140 \pm 25$ & $<0.0001$ \\
\hline Diastolic BP (mmHg) & $67 \pm 9$ & $83 \pm 14$ & $<0.0001$ \\
\hline Fasting plasma glucose (mmol/l) & $4.97 \pm 0.36$ & $7.25 \pm 3.07$ & $<0.0001$ \\
\hline Blood hemoglobin $\mathrm{A}_{1 \mathrm{c}}(\%)$ & $5.39 \pm 0.29$ & $6.58 \pm 1.60$ & $<0.0001$ \\
\hline Serum triglycerides $(\mathrm{mmol} / \mathrm{l})$ & $0.82 \pm 0.30$ & $2.17 \pm 1.46$ & $<0.0001$ \\
\hline Serum HDL-cholesterol (mmol/l) & $1.86 \pm 0.42$ & $1.24 \pm 0.37$ & $<0.0001$ \\
\hline Serum LDL-cholesterol (mmol/l) & $2.95 \pm 0.74$ & $3.28 \pm 0.96$ & $<0.0001$ \\
\hline Chronic kidney disease (\%) & 15.9 & 56.6 & $<0.0001$ \\
\hline Serum creatinine $(\mu \mathrm{mol} / \mathrm{l})$ & $63.0 \pm 18.2$ & $84.4 \pm 97.5$ & $<0.0001$ \\
\hline eGFR $\left.(\mathrm{ml} \mathrm{min})^{-1} 1.73 \mathrm{~m}^{-2}\right)$ & $81.6 \pm 17.0$ & $73.3 \pm 23.5$ & $<0.0001$ \\
\hline Hyperuricemia (\%) & 5.2 & 28.0 & $<0.0001$ \\
\hline Serum uric acid $(\mu \mathrm{mol} / \mathrm{l})$ & $286 \pm 76$ & $356 \pm 97$ & $<0.0001$ \\
\hline
\end{tabular}

Quantitative data are means \pm standard deviations and were compared between subjects with metabolic syndrome and controls with the unpaired Student's t-test. Categorical data were compared between two groups with Pearson's Chi-square test. Base on Bonferroni's correction, a P-value of $<0.0029(0.05 / 17)$ was considered statistically significant. BP, blood pressure; HDL, high density lipoprotein; LDL, low density lipoprotein; eGFR, estimated glomerular filtration rate. Definitions of chronic kidney disease and hyperuricemia are described in Table I.

of identity by descent, with all the pairs of samples showing a value of $>0.1875$ being inspected and one sample from each pair excluded. iv) Heterozygosity of SNPs was calculated for all the samples, and those with extremely low or high heterozygosity ( $>3$ standard deviations from the mean) were discarded. v) SNPs in sex chromosomes or mitochondrial DNA were excluded from the analysis, as were non-polymorphic SNPs or SNPs with a minor allele frequency of $<1.0 \%$. vi) SNPs whose genotype distributions deviated significantly $(\mathrm{P}<0.01)$ from the Hardy-Weinberg equilibrium in control individuals were discarded. vii) Genotype data were examined for population stratification by principal components analysis (62), and population outliers were excluded. Totals of 31,210, 31,521, or 31,142 SNPs passed quality control for the T2DM, MetS, and hyperuricemia studies, respectively, and were subjected to analysis.

Statistical analysis. For analysis of characteristics of the study subjects, quantitative or categorical data were compared between individuals with T2DM, MetS, or hyperuricemia and corresponding controls with the unpaired Student's t-test or Pearson's Chi-square test, respectively. Allele frequencies were estimated by the gene counting method, and Fisher's exact test was used to identify departure from Hardy-Weinberg equilibrium. The relationship of allele frequencies of SNPs to T2DM, MetS, or hyperuricemia in the EWAS was examined using the Fisher's exact test. To compensate for multiple comparisons of allele frequencies with T2DM, MetS, or hyperuricemia, we applied Bonferroni's correction for statistical significance of association. The significance level was set at $\mathrm{P}<1.60 \times 10^{-6}$ $(0.05 / 31210), \mathrm{P}<1.59 \times 10^{-6}(0.05 / 31521)$, or $\mathrm{P}<1.61 \times 10^{-6}$ $(0.05 / 31142)$ for the EWAS of T2DM, MetS, or hyperuricemia, respectively. The inflation factor $(\lambda)$ was 1.04 for T2DM, 1.05 for MetS, or 1.09 for hyperuricemia. Multivariable logistic regression analysis was performed with T2DM, MetS, hyperuricemia as a dependent variable and independent variables including age, sex (0, woman; 1 , man), and genotype of each SNP. Genotypes of each SNP were assessed according to dominant $[0, A A ; 1, A B+B B(A$, major allele; $B$, minor allele $)]$, recessive $(0, A A+A B ; 1, B B)$, and additive genetic models, and the P-value, OR, and $95 \%$ confidence interval were calculated. Additive models comprised additive $1(0, A A ; 1, A B ; 0, B B)$ and additive $2(0, A A ; 0, A B ; 1, B B)$ scenarios, which were analyzed simultaneously with a single statistical model. The relation of genotypes of identified SNPs to T2DM-, MetS-, or hyperuricemia-related traits was examined by one-way analysis of variance (ANOVA). Bonferroni's correction was also applied to other statistical analysis as indicated. Statistical tests were performed with JMP Genomics version 9.0 software (SAS Institute, Cary, NC, USA).

\section{Results}

Characteristics of subjects. The characteristics of the 7,407 subjects enrolled in the T2DM study are shown in Table I. Age, the frequency of men, and the prevalence of obesity, hypertension, dyslipidemia, chronic kidney disease (CKD), and hyperuricemia as well as body mass index (BMI), 
Table III. Characteristics of subjects with hyperuricemia and control individuals.

\begin{tabular}{|c|c|c|c|}
\hline Characteristic & Control & Hyperuricemia & P-value \\
\hline No. of subjects & 6,554 & 1,365 & \\
\hline Age (years) & $51.5 \pm 9.9$ & $52.9 \pm 9.1$ & $<0.0001$ \\
\hline Sex (men/women, \%) & $52.6 / 47.4$ & $90.2 / 9.8$ & $<0.0001$ \\
\hline Smoking $(\%)$ & 38.3 & 61.6 & $<0.0001$ \\
\hline Obesity (\%) & 30.0 & 47.4 & $<0.0001$ \\
\hline Body mass index $\left(\mathrm{kg} / \mathrm{m}^{2}\right)$ & $23.2 \pm 3.5$ & $24.8 \pm 3.8$ & $<0.0001$ \\
\hline Hypertension (\%) & 38.2 & 62.0 & $<0.0001$ \\
\hline Systolic BP (mmHg) & $126 \pm 23$ & $134 \pm 24$ & $<0.0001$ \\
\hline Diastolic BP (mmHg) & $75 \pm 14$ & $82 \pm 15$ & $<0.0001$ \\
\hline Diabetes mellitus (\%) & 20.8 & 31.6 & $<0.0001$ \\
\hline Fasting plasma glucose (mmol/l) & $6.04 \pm 2.38$ & $6.25 \pm 2.27$ & 0.0022 \\
\hline Blood hemoglobin $\mathrm{A}_{1 \mathrm{c}}(\%)$ & $5.96 \pm 1.26$ & $6.10 \pm 1.28$ & 0.0042 \\
\hline Dyslipidemia (\%) & 57.9 & 79.0 & $<0.0001$ \\
\hline Serum triglycerides $(\mathrm{mmol} / \mathrm{l})$ & $1.34 \pm 0.99$ & $1.90 \pm 1.38$ & $<0.0001$ \\
\hline Serum HDL-cholesterol (mmol/l) & $1.57 \pm 0.47$ & $1.37 \pm 0.42$ & $<0.0001$ \\
\hline Serum LDL-cholesterol (mmol/l) & $3.15 \pm 0.85$ & $3.20 \pm 0.93$ & 0.0506 \\
\hline Chronic kidney disease $(\%)$ & 11.0 & 33.0 & $<0.0001$ \\
\hline Serum creatinine $(\mu \mathrm{mol} / \mathrm{l})$ & $68.7 \pm 52.3$ & $109.4 \pm 150.3$ & $<0.0001$ \\
\hline eGFR (ml min $\left.{ }^{-1} 1.73 \mathrm{~m}^{-2}\right)$ & $79.2 \pm 18.3$ & $67.4 \pm 25.8$ & $<0.0001$ \\
\hline Serum uric acid $(\mu \mathrm{mol} / \mathrm{l})$ & $296 \pm 67$ & $455 \pm 78$ & $<0.0001$ \\
\hline
\end{tabular}

systolic and diastolic BP, and serum concentrations of triglycerides, creatinine, and uric acid were greater, whereas serum concentration of HDL-cholesterol and estimated glomerular filtration rate (eGFR) were lower, in subjects with T2DM than in controls.

Characteristics of the 4,215 subjects enrolled in the MetS study are shown in Table II. Age, the frequency of men, and the prevalence of smoking, CKD, and hyperuricemia as well as BMI, blood hemoglobin $\mathrm{A}_{1 \mathrm{c}}$ content, and serum concentrations of low-density lipoprotein (LDL) cholesterol, creatinine, and uric acid were greater, whereas eGFR were lower, in subjects with MetS than in controls.

Characteristics of the 7,919 subjects enrolled in the hyperuricemia study are shown in Table III. Age, the frequency of men, and the prevalence of smoking, obesity, hypertension, DM, dyslipidemia, and CKD as well as BMI, systolic and diastolic BP, FPG level, and serum concentrations of triglycerides and creatinine were greater, whereas the serum concentration of HDL-cholesterol and eGFR were lower, in subjects with hyperuricemia than in controls.

EWAS for T2DM, MetS, or hyperuricemia. We examined the relationship of allele frequencies of 31,210 SNPs that passed quality control to T2DM with the use of Fisher's exact test. After Bonferroni's correction, four SNPs were significantly $\left(\mathrm{P}<1.60 \times 10^{-6}\right)$ associated with T2DM (Table IV). The relationship of allele frequencies of 31,521 SNPs to MetS was examined with Fisher's exact test. After Bonferroni's correction, six SNPs were significantly $\left(\mathrm{P}<1.59 \times 10^{-6}\right)$ associated with MetS (Table V). The relationship of allele frequencies of 31,142 SNPs to hyperuricemia was also examined with Fisher's exact test. After Bonferroni's correction, nine SNPs were significantly $\left(\mathrm{P}<1.61 \times 10^{-6}\right)$ associated with hyperuricemia (Table VI).

Multivariable logistic regression analysis of the relationship of SNPs to T2DM, MetS, or hyperuricemia. The relationship of the four identified SNPs in the EWAS of T2DM to this condition was further examined by multivariable logistic regression analysis with adjustment for age and sex (Table VII). Three SNPs (rs141569282 of OR4F6, rs140232911 of ZNF860, rs150552771 of LPGAT1) were significantly [P $<0.0031$ $(0.05 / 16)$ in at least one genetic model] related to T2DM. The relationship of the six SNPs identified in the EWAS for MetS to this condition was examined by multivariable logistic regression analysis with adjustment for age and sex (Table VIII). All the SNPs were significantly $[\mathrm{P}<0.0021(0.05 / 24)]$ related to MetS. The relationship of the 9 SNPs identified by the EWAS of hyperuricemia to this condition was also examined by multivariable logistic regression analysis with adjustment for age and sex (Table IX). All SNPs were significantly $[\mathrm{P}<0.0014$ $(0.05 / 36)]$ related to hyperuricemia. 

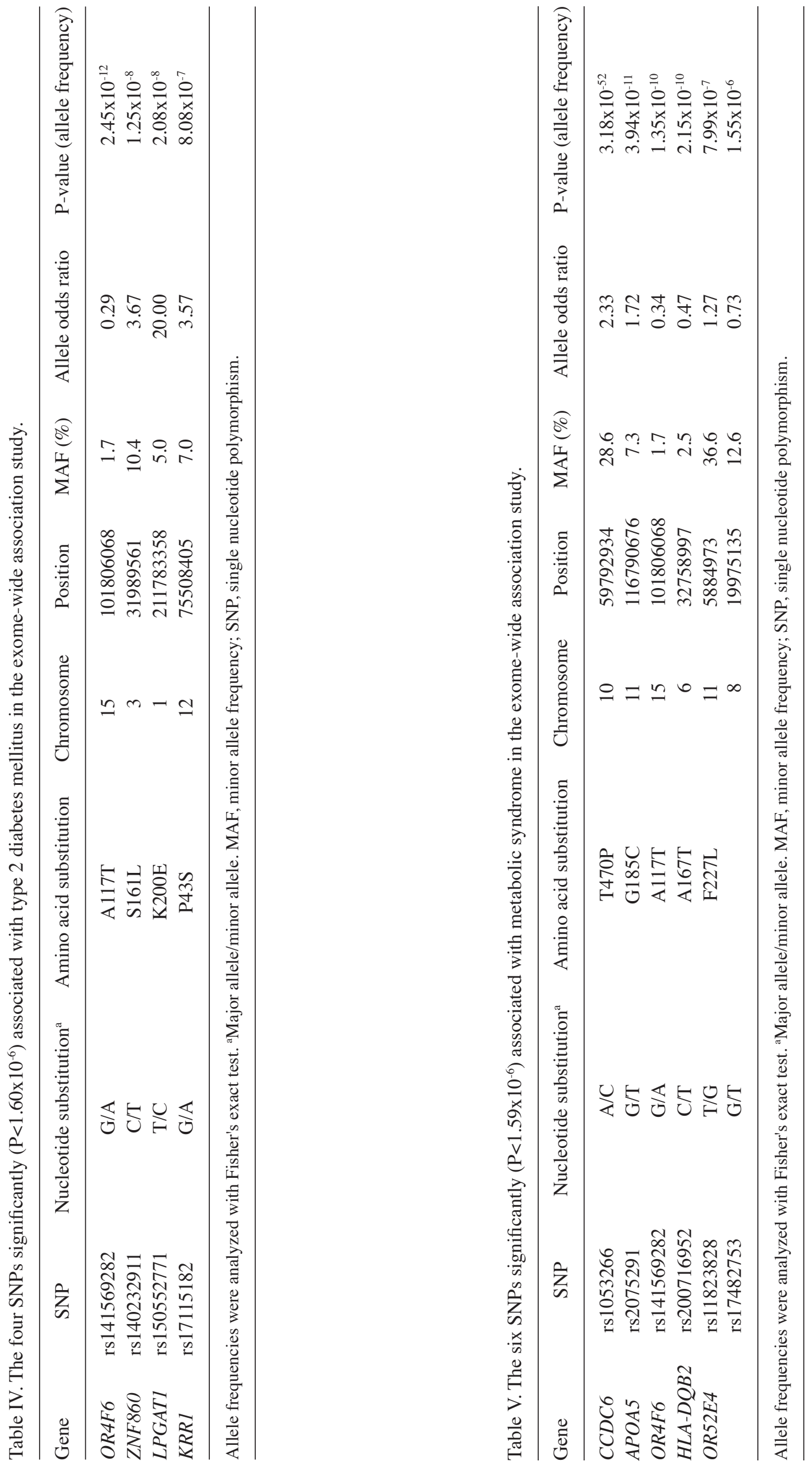

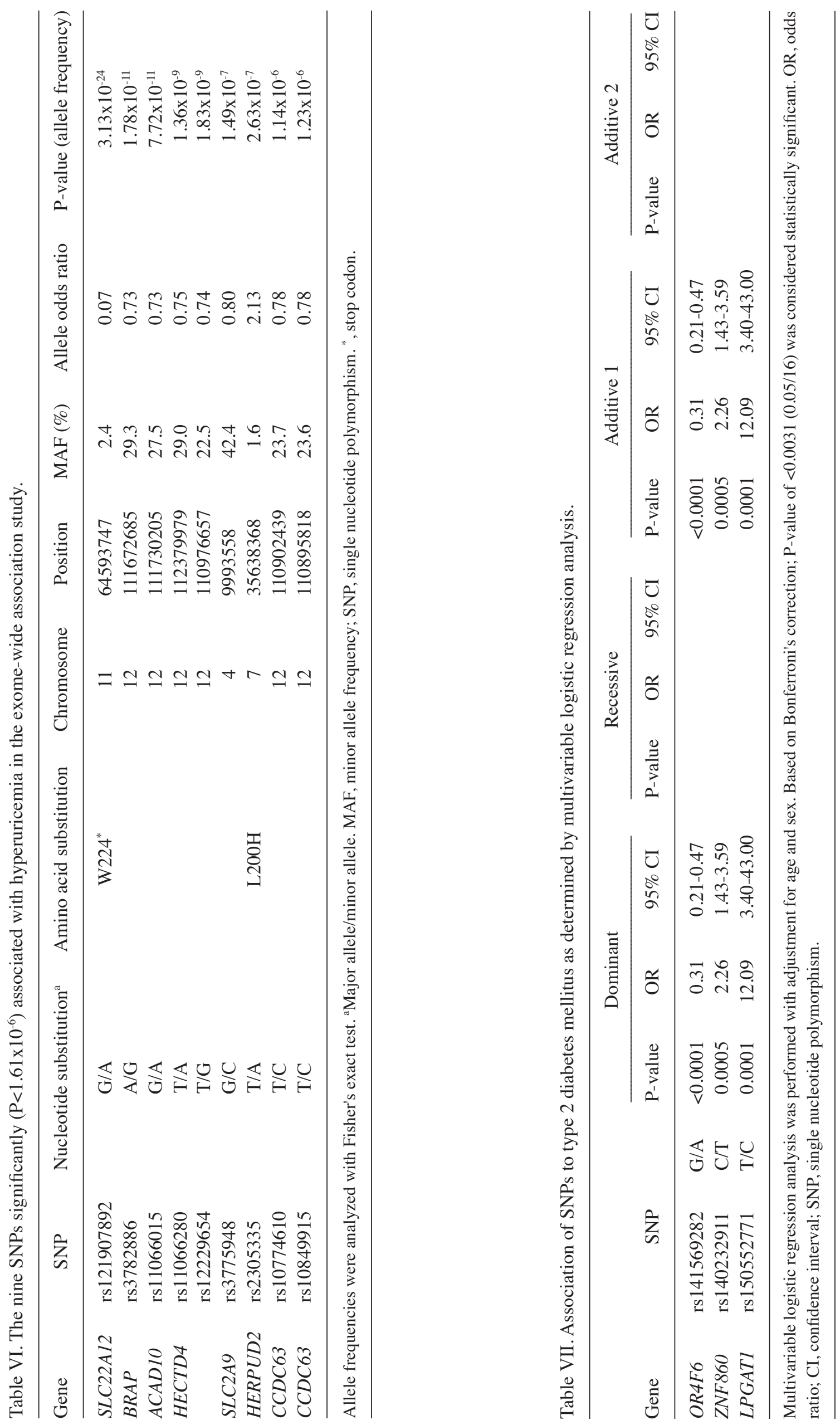

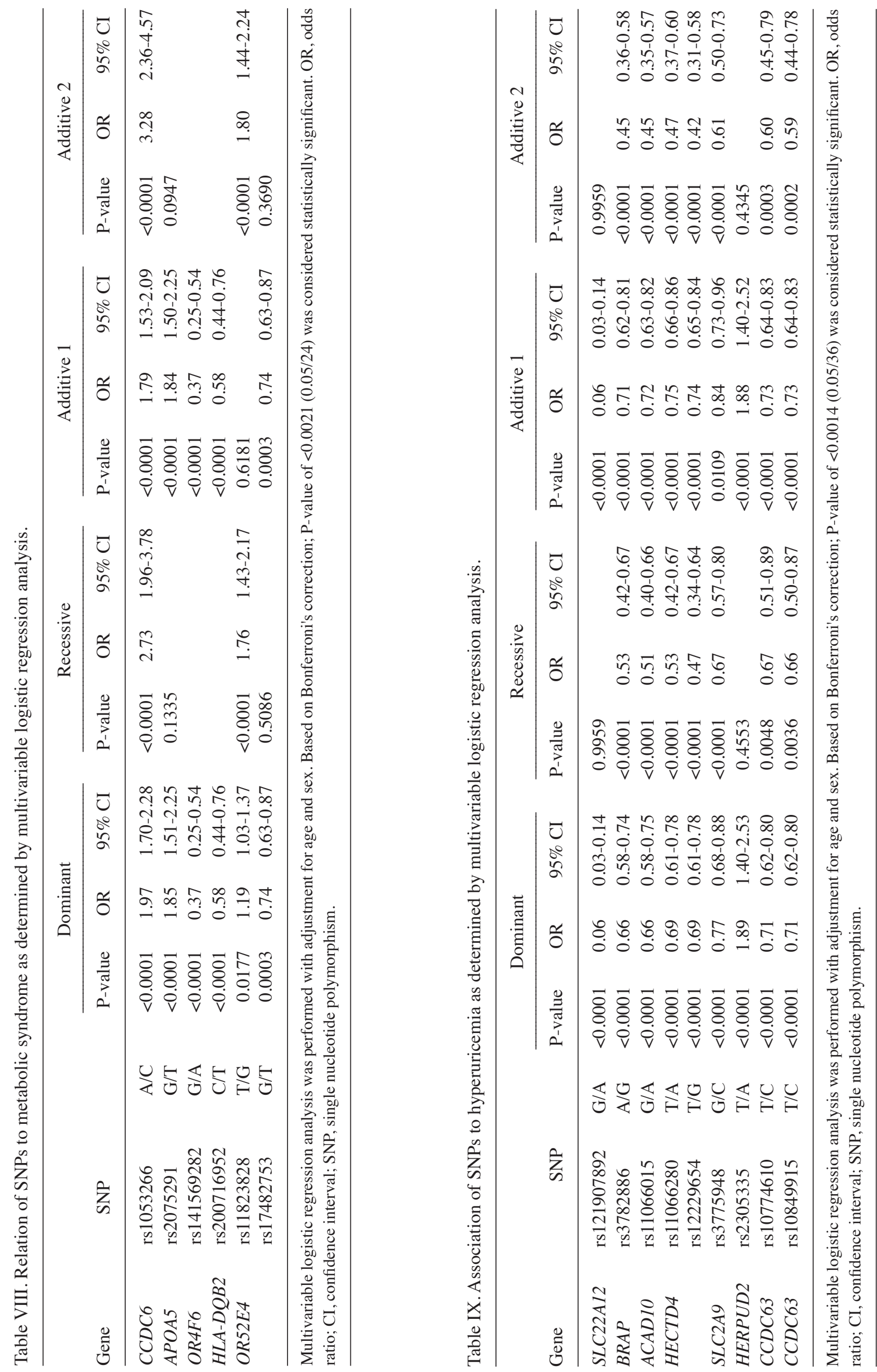
Table X. Relation of SNPs identified in the present study to fasting plasma glucose level and blood hemoglobin $\mathrm{A}_{1 \mathrm{c}}$ content.

\begin{tabular}{|c|c|c|c|c|c|c|c|c|}
\hline \multirow{2}{*}{$\begin{array}{l}\text { Gene } \\
\text { OR4F6 }\end{array}$} & \multicolumn{2}{|l|}{ SNP } & \multicolumn{2}{|c|}{ Pasting plasma glucose $(\mathrm{mmol} / \mathrm{l})$} & \multirow{2}{*}{$\begin{array}{c}\text { P-value } \\
<\mathbf{0 . 0 0 0 1}\end{array}$} & \multicolumn{2}{|c|}{ Blood hemoglobin $\mathrm{A}_{1 \mathrm{c}}(\%)$} & \multirow{2}{*}{$\begin{array}{c}\text { P-value } \\
<\mathbf{0 . 0 0 0 1}\end{array}$} \\
\hline & rs 141569282 & $\mathrm{G} / \mathrm{A}$ & $\begin{array}{c}\mathrm{GG} \\
6.26 \pm 2.76\end{array}$ & $\begin{array}{c}\text { GA } \\
5.35 \pm 0.71\end{array}$ & & $\begin{array}{c}\mathrm{GG} \\
6.15 \pm 1.46\end{array}$ & $\begin{array}{c}\text { GA } \\
5.57 \pm 0.43\end{array}$ & \\
\hline ZNF860 & rs140232911 & $\mathrm{C} / \mathrm{T}$ & $\begin{array}{c}\mathrm{CC} \\
6.06 \pm 2.46\end{array}$ & $\begin{array}{c}\text { CT } \\
6.25 \pm 1.97\end{array}$ & 0.6279 & $\begin{array}{c}\mathrm{CC} \\
5.52 \pm 0.73\end{array}$ & $\begin{array}{c}\mathrm{CT} \\
6.00 \pm 1.32\end{array}$ & 0.0070 \\
\hline LPGAT1 & rs 150552771 & $\mathrm{~T} / \mathrm{C}$ & $\begin{array}{c}\mathrm{TT} \\
6.05 \pm 2.45\end{array}$ & $\begin{array}{c}\mathrm{TC} \\
6.63 \pm 3.88\end{array}$ & 0.6320 & $\begin{array}{c}\mathrm{TT} \\
5.35 \pm 0.53\end{array}$ & $\begin{array}{c}\text { TC } \\
5.99 \pm 1.31\end{array}$ & 0.3280 \\
\hline
\end{tabular}

Data are means \pm standard deviations and compared among genotypes by one-way analysis of variance. Based on Bonferroni's correction, P-values of $<0.0083(0.05 / 6)$ were considered statistically significant and are shown in bold. SNP, single nucleotide polymorphism.

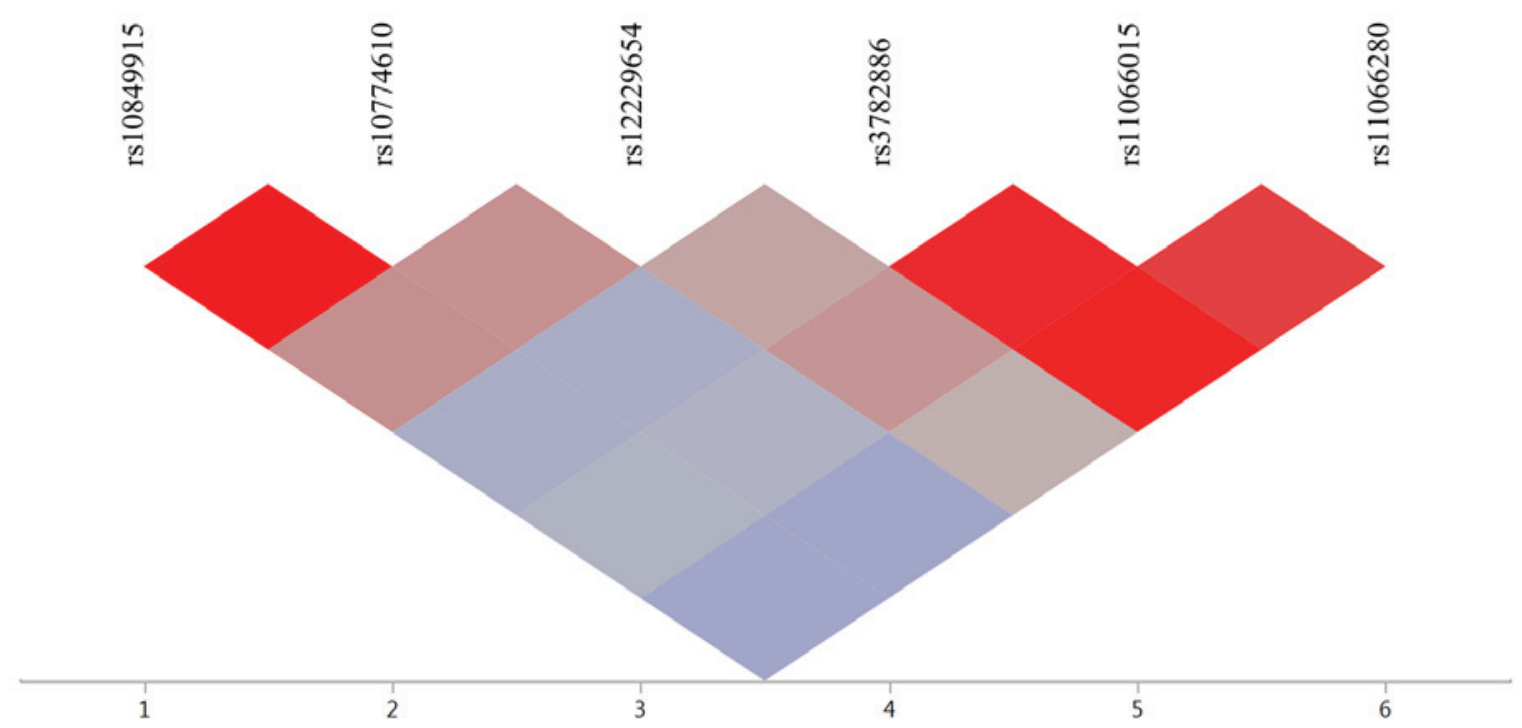

Figure 1. LD map of six SNPs at $12 q 24.11$ to $12 q 24.13$ associated with hyperuricemia. LD was calculated as the square of the correlation coefficient $\left(\mathrm{r}^{2}\right)$ and the strength of LD increases according to the color order of blue $<$ gray $<$ red. LD, linkage disequilibrium.

Relationship of SNPs associated with T2DM to FPG level or blood hemoglobin $A_{1 c}$ content. We examined the relationship of genotypes for the 3 SNPs associated with T2DM to FPG level or blood hemoglobin $\mathrm{A}_{1 \mathrm{c}}$ content by one-way ANOVA (Table X). A SNP rs141569282 of OR4F6 was significantly $[\mathrm{P}<0.0083(0.05 / 6)]$ associated with FPG level and blood hemoglobin $\mathrm{A}_{1 \mathrm{c}}$ content, and rs140232911 of ZNF860 with blood hemoglobin $\mathrm{A}_{1 \mathrm{c}}$ content.

Relationship of SNPs associated with MetS to each trait of MetS. We examined the relationship of genotypes for the six SNPs associated with MetS to waist circumference, serum concentrations of triglycerides and HDL-cholesterol, systolic and diastolic BP, and FPG level by one-way ANOVA (Table XI). Three SNPs (rs1053266 of CCDC6, rs141569282 of $O R 4 F 6$, rs200716952 of $H L A-D Q B 2)$ were significantly $(\mathrm{P}<0.0014)$ related to all the traits; rs2075291 of $A P O A 5$ to waist circumference and serum concentrations of triglycerides and HDL-cholesterol; rs11823828 of OR52E4 to serum concentrations of triglycerides and HDL-cholesterol, systolic BP, and FPG level; and rs17482753 at chromosome 8 p21.3 to serum concentrations of triglycerides and HDL-cholesterol.
Relationship of SNPs associated with hyperuricemia to serum concentrations of uric acid. We examined the relationship of the 9 SNPs associated with hyperuricemia to serum concentrations of uric acid by one-way ANOVA (Table XII). Seven SNPs (rs121907892 of SLC22A12, rs3782886 of BRAP, rs11066015 of ACAD10, rs11066280 of HECTD4, rs12229654 at chromosome 12q24.1, rs3775948 of SLC2A9, rs2305335 of HERPUD2) were significantly $(\mathrm{P}<0.0056)$ associated with serum concentrations of uric acid.

Linkage disequilibrium (LD) analyses. We examined LD in SNPs associated with MetS or hyperuricemia. For the MetS study, rs11823828 of OR52E4 and rs2075291 of APOA5 were not in LD [square of the correlation coefficient $\left.\left(\mathrm{r}^{2}\right)<0.001\right]$. For the hyperuricemia study, 6 SNPs were located at chromosomal $12 \mathrm{q} 24.11$ to $12 \mathrm{q} 24.13$. LD plots of these SNPs are shown in Fig. 1. Strong LD was observed between rs10849915 and rs10774610 of CCDC63 $\left(\mathrm{r}^{2}, 0.991\right)$ and among rs3782886 of $B R A P$, rs11066015 of ACADIO, and rs11066280 of HECTD4 $\left(\mathrm{r}^{2}, 0.876\right.$ to 0.941$)$.

Relation of genes, chromosomal loci, and SNPs identified in the present study to phenotypes reported by previous GWASs. 
Table XI. Relationship of SNPs identified in the present study to each trait of metabolic syndrome.

\begin{tabular}{|c|c|c|c|c|c|c|}
\hline \multirow{2}{*}{$\frac{\text { Gene }}{\text { CCDC6 }}$} & \multicolumn{2}{|c|}{ SNP } & \multicolumn{3}{|c|}{ Waist circumference $(\mathrm{cm})$} & \multirow{2}{*}{$\begin{array}{c}\text { P-value } \\
<\mathbf{0 . 0 0 0 1}\end{array}$} \\
\hline & rs 1053266 & $\mathrm{~A} / \mathrm{C}$ & $\begin{array}{c}\mathrm{AA} \\
81.0 \pm 10.6\end{array}$ & $\begin{array}{c}\mathrm{AC} \\
83.8 \pm 10.4\end{array}$ & $\begin{array}{c}\mathrm{CC} \\
87.0 \pm 8.6\end{array}$ & \\
\hline APOA5 & rs2075291 & $\mathrm{G} / \mathrm{T}$ & $\begin{array}{c}\mathrm{GG} \\
82.0 \pm 10.6\end{array}$ & $\begin{array}{c}\text { GT } \\
83.7 \pm 10.3\end{array}$ & $\begin{array}{c}\mathrm{TT} \\
82.8 \pm 10.3\end{array}$ & 0.0012 \\
\hline OR4F6 & rs 141569282 & $\mathrm{G} / \mathrm{A}$ & $\begin{array}{c}\mathrm{GG} \\
83.2 \pm 10.4\end{array}$ & $\begin{array}{c}\text { GA } \\
79.1 \pm 10.8\end{array}$ & & $<0.0001$ \\
\hline$H L A-D Q B 2$ & rs200716952 & $\mathrm{C} / \mathrm{T}$ & $\begin{array}{c}\mathrm{CC} \\
82.5 \pm 10.5\end{array}$ & $\begin{array}{c}\text { CT } \\
79.5 \pm 10.7\end{array}$ & & $<0.0001$ \\
\hline OR52E4 & rs11823828 & $\mathrm{T} / \mathrm{G}$ & $\begin{array}{c}\text { TT } \\
81.8 \pm 10.8\end{array}$ & $\begin{array}{c}\text { TG } \\
81.8 \pm 10.8\end{array}$ & $\begin{array}{c}\mathrm{GG} \\
83.2 \pm 10.3\end{array}$ & 0.0159 \\
\hline & rs 17482753 & $\mathrm{G} / \mathrm{T}$ & $\begin{array}{c}\text { GG } \\
82.5 \pm 10.7\end{array}$ & $\begin{array}{c}\text { GT } \\
81.3 \pm 10.3\end{array}$ & $\begin{array}{c}\text { TT } \\
83.2 \pm 10.9\end{array}$ & 0.0070 \\
\hline Gene & SN & & & iglycerides ( & & P-value \\
\hline CCDC6 & rs 1053266 & $\mathrm{~A} / \mathrm{C}$ & $\begin{array}{c}\mathrm{AA} \\
1.45 \pm 1.21\end{array}$ & $\begin{array}{c}\mathrm{AC} \\
1.79 \pm 1.46\end{array}$ & $\begin{array}{c}\mathrm{CC} \\
2.13 \pm 1.33\end{array}$ & $<0.0001$ \\
\hline APOA5 & rs2075291 & $\mathrm{G} / \mathrm{T}$ & $\begin{array}{c}\text { GG } \\
1.51 \pm 1.15\end{array}$ & $\begin{array}{c}\mathrm{GT} \\
2.06 \pm 1.84\end{array}$ & $\begin{array}{c}\text { TT } \\
2.71 \pm 2.63\end{array}$ & $<0.0001$ \\
\hline OR4F6 & rs 141569282 & G/A & $\begin{array}{c}\mathrm{GG} \\
1.71 \pm 1.38\end{array}$ & $\begin{array}{c}\text { GA } \\
1.19 \pm 1.00\end{array}$ & & $<0.0001$ \\
\hline$H L A-D Q B 2$ & rs200716952 & $\mathrm{C} / \mathrm{T}$ & $\begin{array}{c}\mathrm{CC} \\
1.62 \pm 1.32\end{array}$ & $\begin{array}{c}\text { CT } \\
1.26 \pm 1.11\end{array}$ & & $<0.0001$ \\
\hline OR52E4 & rs11823828 & $\mathrm{T} / \mathrm{G}$ & $\begin{array}{c}\mathrm{TT} \\
1.52 \pm 1.22\end{array}$ & $\begin{array}{c}\text { TG } \\
1.49 \pm 1.15\end{array}$ & $\begin{array}{c}\mathrm{GG} \\
1.74 \pm 1.41\end{array}$ & 0.0003 \\
\hline & rs 17482753 & $\mathrm{G} / \mathrm{T}$ & $\begin{array}{c}\mathrm{GG} \\
1.65 \pm 1.32\end{array}$ & $\begin{array}{c}\mathrm{GT} \\
1.41 \pm 1.22\end{array}$ & $\begin{array}{c}\mathrm{TT} \\
1.55 \pm 1.72\end{array}$ & $<0.0001$ \\
\hline
\end{tabular}

\begin{tabular}{|c|c|c|c|c|c|c|}
\hline \multirow{3}{*}{$\frac{\text { Gene }}{C C D C 6}$} & \multicolumn{2}{|c|}{ SNP } & \multicolumn{3}{|c|}{ Serum HDL-cholesterol (mmol/l) } & \multirow{3}{*}{$\begin{array}{c}\text { P-value } \\
<0.0001\end{array}$} \\
\hline & rs 1053266 & $\mathrm{~A} / \mathrm{C}$ & AA & $\mathrm{AC}$ & $\mathrm{CC}$ & \\
\hline & & & $1.59 \pm 0.49$ & $1.39 \pm 0.48$ & $1.17 \pm 0.35$ & \\
\hline \multirow[t]{2}{*}{ APOA5 } & rs2075291 & $\mathrm{G} / \mathrm{T}$ & GG & GT & $\mathrm{TT}$ & $<0.0001$ \\
\hline & & & $1.53 \pm 0.50$ & $1.38 \pm 0.48$ & $1.28 \pm 0.43$ & \\
\hline \multirow[t]{2}{*}{ OR4F6 } & rs 141569282 & $\mathrm{G} / \mathrm{A}$ & GG & GA & & $<0.0001$ \\
\hline & & & $1.44 \pm 0.49$ & $1.72 \pm 0.42$ & & \\
\hline \multirow[t]{2}{*}{$H L A-D Q B 2$} & rs 200716952 & $\mathrm{C} / \mathrm{T}$ & $\mathrm{CC}$ & $\mathrm{CT}$ & & $<0.0001$ \\
\hline & & & $1.49 \pm 0.47$ & $1.69 \pm 0.47$ & & \\
\hline \multirow[t]{4}{*}{ OR52E4 } & rs11823828 & $\mathrm{T} / \mathrm{G}$ & TT & TG & GG & 0.0001 \\
\hline & & & $1.54 \pm 0.49$ & $1.54 \pm 0.51$ & $1.44 \pm 0.47$ & \\
\hline & rs 17482753 & $\mathrm{G} / \mathrm{T}$ & GG & GT & TT & $<0.0001$ \\
\hline & & & $1.48 \pm 0.49$ & $1.58 \pm 0.53$ & $1.62 \pm 0.52$ & \\
\hline Gene & \multicolumn{2}{|c|}{ SNP } & \multicolumn{3}{|c|}{ Systolic blood pressure $(\mathrm{mmHg})$} & P-value \\
\hline \multirow[t]{2}{*}{ CCDC6 } & rs 1053266 & $\mathrm{~A} / \mathrm{C}$ & AA & $\mathrm{AC}$ & $\mathrm{CC}$ & $<0.0001$ \\
\hline & & & $122 \pm 22$ & $134 \pm 28$ & $145 \pm 26$ & \\
\hline \multirow{2}{*}{ APOA5 } & rs2075291 & $\mathrm{G} / \mathrm{T}$ & GG & GT & TT & 0.0493 \\
\hline & & & $127 \pm 25$ & $130 \pm 24$ & $132 \pm 30$ & \\
\hline \multirow[t]{2}{*}{ OR4F6 } & rs 141569282 & $\mathrm{G} / \mathrm{A}$ & GG & GA & & $<0.0001$ \\
\hline & & & $131 \pm 27$ & $115 \pm 16$ & & \\
\hline \multirow[t]{2}{*}{$H L A-D Q B 2$} & rs 200716952 & $\mathrm{C} / \mathrm{T}$ & $\mathrm{CC}$ & $\mathrm{CT}$ & & $<0.0001$ \\
\hline & & & $128 \pm 26$ & $117 \pm 17$ & & \\
\hline \multirow[t]{4}{*}{ OR52E4 } & rs11823828 & $\mathrm{T} / \mathrm{G}$ & TT & TG & GG & $<0.0001$ \\
\hline & & & $125 \pm 24$ & $126 \pm 25$ & $130 \pm 25$ & \\
\hline & rs 17482753 & $\mathrm{G} / \mathrm{T}$ & GG & GT & TT & 0.0616 \\
\hline & & & $128 \pm 25$ & $126 \pm 25$ & $130 \pm 23$ & \\
\hline
\end{tabular}


Table XI. Continued.

\begin{tabular}{|c|c|c|c|c|c|c|}
\hline \multirow{3}{*}{$\begin{array}{l}\text { Gene } \\
C C D C 6\end{array}$} & \multicolumn{2}{|c|}{ SNP } & \multicolumn{3}{|c|}{ Diastolic blood pressure (mmHg) } & \multirow{2}{*}{$\begin{array}{c}\text { P-value } \\
<0.0001\end{array}$} \\
\hline & rs1053266 & $\mathrm{A} / \mathrm{C}$ & $\mathrm{AA}$ & $\mathrm{AC}$ & $\mathrm{CC}$ & \\
\hline & & & $75 \pm 14$ & $79 \pm 16$ & $82 \pm 16$ & \\
\hline \multirow[t]{2}{*}{ APOA5 } & rs2075291 & $\mathrm{G} / \mathrm{T}$ & GG & GT & TT & 0.0055 \\
\hline & & & $76 \pm 15$ & $78 \pm 14$ & $80 \pm 13$ & \\
\hline \multirow[t]{2}{*}{ OR4F6 } & rs141569282 & $\mathrm{G} / \mathrm{A}$ & GG & GA & & $<0.0001$ \\
\hline & & & $78 \pm 15$ & $71 \pm 13$ & & \\
\hline \multirow[t]{2}{*}{$H L A-D Q B 2$} & rs200716952 & $\mathrm{C} / \mathrm{T}$ & $\mathrm{CC}$ & $\mathrm{CT}$ & & 0.0002 \\
\hline & & & $77 \pm 15$ & $73 \pm 13$ & & \\
\hline \multirow[t]{4}{*}{ OR52E4 } & rs11823828 & $\mathrm{T} / \mathrm{G}$ & TT & TG & GG & 0.5502 \\
\hline & & & $76 \pm 15$ & $76 \pm 15$ & $76 \pm 14$ & \\
\hline & rs17482753 & $\mathrm{G} / \mathrm{T}$ & GG & GT & TT & 0.3685 \\
\hline & & & $76 \pm 15$ & $76 \pm 15$ & $77 \pm 14$ & \\
\hline Gene & \multicolumn{2}{|c|}{ SNP } & \multicolumn{3}{|c|}{ Fasting plasma glucose (mmol/l) } & P-value \\
\hline \multirow[t]{2}{*}{ CCDC6 } & rs1053266 & $\mathrm{A} / \mathrm{C}$ & AA & $\mathrm{AC}$ & $\mathrm{CC}$ & $<0.0001$ \\
\hline & & & $5.90 \pm 2.05$ & $6.90 \pm 3.33$ & $7.41 \pm 3.02$ & \\
\hline \multirow[t]{2}{*}{ APOA5 } & rs2075291 & $\mathrm{G} / \mathrm{T}$ & GG & GT & TT & 0.2227 \\
\hline & & & $6.25 \pm 2.57$ & $6.46 \pm 2.77$ & $6.15 \pm 1.77$ & \\
\hline \multirow[t]{2}{*}{ OR4F6 } & rs141569282 & $\mathrm{G} / \mathrm{A}$ & GG & GA & & $<0.0001$ \\
\hline & & & $6.53 \pm 2.87$ & $5.34 \pm 0.76$ & & \\
\hline \multirow[t]{2}{*}{$H L A-D Q B 2$} & rs200716952 & $\mathrm{C} / \mathrm{T}$ & $\mathrm{CC}$ & $\mathrm{CT}$ & & $<0.0001$ \\
\hline & & & $6.36 \pm 2.67$ & $5.41 \pm 1.05$ & & \\
\hline \multirow[t]{4}{*}{ OR52E4 } & rs11823828 & $\mathrm{T} / \mathrm{G}$ & TT & TG & GG & 0.0001 \\
\hline & & & $6.09 \pm 2.32$ & $6.07 \pm 2.30$ & $6.57 \pm 2.95$ & \\
\hline & rs17482753 & $\mathrm{G} / \mathrm{T}$ & GG & GT & $\mathrm{TT}$ & 0.0048 \\
\hline & & & $6.35 \pm 2.63$ & $6.03 \pm 2.42$ & $6.55 \pm 2.78$ & \\
\hline
\end{tabular}

Data are means \pm standard deviations and compared among genotypes by one-way analysis of variance. Based on Bonferroni's correction, P-values of $<0.0014(0.05 / 36)$ were considered statistically significant and are shown in bold. SNP, single nucleotide polymorphism.

We examined the genes, chromosomal loci, and SNPs identified in the present study to phenotypes previously reported by GWASs available in Genome-Wide Repository of Associations Between SNPs and Phenotypes (GRASP) Search database (https://grasp.nhlbi.nih.gov/Search.aspx) developed by the Information Technology and Applications Center, National Center for Biotechnology Information, National Heart, Lung, and Blood Institute, National Institute of Health (Bethesda, MD, USA).

In the T2DM study, none of the three genes or SNPs was shown to be associated with T2DM or diabetes-related traits in previous GWASs (Table XIII). In the MetS study, HLA-DQB2 was shown to be related to T1DM and plasma total cholesterol; rs17482753 at chromosome 8p21.3 to plasma concentrations of triglycerides and HDL-cholesterol; CCDC6 to serum uric acid level; and APOA5 to plasma concentrations of triglycerides, HDL-cholesterol, and LDL-cholesterol (Table XIV). In the hyperuricemia study, SLC2A9, SLC22A12, and BRAP were shown to be related to serum uric acid concentrations; rs12229654 at 12q24.1 to plasma HDL-cholesterol; ACAD10 to plasma LDL-cholesterol and T1DM; and HECTD4 to plasma HDL-cholesterol and LDL-cholesterol and FPG level (Table XV).

\section{Discussion}

T2DM, MetS, and hyperuricemia are important public health problems because of the high prevalence of these conditions as well as risk factors for more serious conditions such as cardiovascular disease, cancer, or gout (1,3,4,23,24,33-35). Identification of genetic variants that confer susceptibility to T2DM, MetS, and hyperuricemia are thus clinically important to prevent these conditions. We have now performed EWASs for T2DM, MetS, and hyperuricemia in early-onset subjects with these conditions who likely had greater genetic components compared with late-onset individuals.

In the T2DM study, rs150552771 of LPGAT1, rs140232911 of ZNF860, and rs141569282 of OR4F6 were significantly associated with early-onset T2DM. None of these genes was shown to be associated with T2DM or diabetes-related traits in the previous GWASs. Given that rs150552771 of LPGAT1 was not related to FPG level or blood hemoglobin $\mathrm{A}_{1 \mathrm{c}}$ content, LPGAT1 was removed from new susceptibility locus, even though this discrepancy may be attributable to the effect of medical treatment for T2DM. We have thus newly identified ZNF860 and OR4F6 as susceptibility loci for T2DM. A SNP rs141569282 of OR4F6 was significantly related to FPG level 
Table XII. Relationship of SNPs identified in the present study to the serum concentration of uric acid.

\begin{tabular}{|c|c|c|c|c|c|c|}
\hline \multirow{3}{*}{$\frac{\text { Gene }}{S L C 22 A 12}$} & \multicolumn{2}{|c|}{ SNP } & \multicolumn{3}{|c|}{ Serum uric acid $(\mu \mathrm{mol} / \mathrm{l})$} & \multirow{3}{*}{$\begin{array}{l}\text { P-value } \\
<0.0001\end{array}$} \\
\hline & rs121907892 & $\mathrm{G} / \mathrm{A}$ & GG & GA & AA & \\
\hline & & & $333 \pm 91$ & $231 \pm 82$ & $52 \pm 19$ & \\
\hline \multirow[t]{2}{*}{$B R A P$} & rs3782886 & $\mathrm{A} / \mathrm{G}$ & AA & $\mathrm{AG}$ & GG & 0.0002 \\
\hline & & & $332 \pm 97$ & $324 \pm 91$ & $318 \pm 88$ & \\
\hline \multirow[t]{2}{*}{$A C A D 10$} & rs 11066015 & $\mathrm{G} / \mathrm{A}$ & GG & GA & AA & 0.0004 \\
\hline & & & $332 \pm 97$ & $324 \pm 91$ & $319 \pm 88$ & \\
\hline \multirow[t]{4}{*}{ HECTD4 } & rs 11066280 & $\mathrm{~T} / \mathrm{A}$ & TT & TA & $\mathrm{AA}$ & 0.0006 \\
\hline & & & $332 \pm 96$ & $325 \pm 92$ & $318 \pm 87$ & \\
\hline & rs 12229654 & $\mathrm{~T} / \mathrm{G}$ & TT & TG & GG & 0.0002 \\
\hline & & & $331 \pm 96$ & $326 \pm 91$ & $312 \pm 84$ & \\
\hline \multirow{2}{*}{ SLC2A9 } & rs 3775948 & $\mathrm{G} / \mathrm{C}$ & GG & $\mathrm{GC}$ & $\mathrm{CC}$ & $<0.0001$ \\
\hline & & & $335 \pm 94$ & $328 \pm 92$ & $312 \pm 96$ & \\
\hline \multirow[t]{2}{*}{ HERPUD 2} & rs 2305335 & $\mathrm{~T} / \mathrm{A}$ & TT & TA & $\mathrm{AA}$ & $<0.0001$ \\
\hline & & & $327 \pm 93$ & $358 \pm 116$ & $407 \pm 88$ & \\
\hline \multirow[t]{2}{*}{$C C D C 63$} & rs 10774610 & $\mathrm{~T} / \mathrm{C}$ & $\mathrm{TT}$ & $\mathrm{TC}$ & $\mathrm{CC}$ & 0.0067 \\
\hline & & & $330 \pm 96$ & $325 \pm 91$ & $318 \pm 92$ & \\
\hline \multirow[t]{2}{*}{$C C D C 63$} & rs 10849915 & $\mathrm{~T} / \mathrm{C}$ & TT & $\mathrm{TC}$ & $\mathrm{CC}$ & 0.0083 \\
\hline & & & $330 \pm 96$ & $325 \pm 91$ & $318 \pm 92$ & \\
\hline
\end{tabular}

Data were means \pm standard deviations and compared among genotypes by one-way analysis of variance. Based on Bonferroni's correction, P-values of $<0.0056(0.05 / 9)$ were considered statistically significant and are shown in bold. SNP, single nucleotide polymorphism.

Table XIII. Relationship of genes and SNPs associated with type 2 diabetes mellitus in the present study to previously reported diabetes-related phenotypes.

\begin{tabular}{lcccc}
\hline Gene & SNP & Chromosome & Position & Previously reported phenotypes \\
\hline LPGAT1 & rs150552771 & 1 & 211783358 & None \\
ZNF860 & rs140232911 & 3 & 31989561 & None \\
OR4F6 & rs141569282 & 15 & 101806068 & None \\
\hline
\end{tabular}

Data were obtained from Genome-wide repository of associations between SNPs and phenotypes (GRASP) search database (https:/grasp. nhlbi.nih.gov/Search.aspx) with a P-value of $<1.0 \times 10^{-6}$. SNP, single nucleotide polymorphism.

and blood hemoglobin $\mathrm{A}_{1 \mathrm{c}}$ content with the minor $A$ allele being related to decreases in these parameters, while rs140232911 of ZNF860 was related to blood hemoglobin $\mathrm{A}_{1 \mathrm{c}}$ content with the minor $T$ allele being related to an increase in this parameter. Analyses of these traits as well as logistic regression analysis indicate that the $A$ allele of rs141569282 in OR4F6 is protective against T2DM, whereas the $T$ allele of rs140232911 in ZNF860 is a risk factor for this condition.

In the MetS study, six SNPs in five genes and one chromosomal locus were significantly associated with early-onset MetS. Of these genes and locus, $H L A-D Q B 2$ (63), rs17482753 at $8 \mathrm{p} 21.3$ (63), and APOA5 (63) were previously shown to be related to lipid profiles; and $C C D C 6$ to serum uric acid level (46). OR52E4 or OR4F6 has not been shown to be associated with MetS or MetS-related traits in the previous GWASs. A SNP rs11823828 of OR52E4 was significantly related to serum concentrations of triglycerides and HDL-cholesterol, systolic BP, and FPG level; and rs141569282 of OR4F6 to all traits. We have thus newly identified OR52E4 and OR4F6 as susceptibility loci for MetS. The minor $G$ allele of rs11823828 in OR52E4 was significantly related to increased serum triglycerides, decreased serum HDL-cholesterol, increased systolic BP, and increased FPG level, whereas the minor $A$ allele of rs141569282 in OR4F6 was related to reduced waist circumference, decreased serum triglycerides, increased serum HDL-cholesterol, decreased systolic and diastolic BP, and reduced FPG level. Analyses of these traits and logistic regression analysis indicate that the $G$ allele of rs11823828 in $O R 52 E 4$ represents a risk factor for MetS, whereas the $A$ allele of rs141569282 in OR4F6 is protective against this condition.

In the hyperuricemia study, 9 SNPs in seven genes and one chromosomal locus were significantly associated with early-onset hyperuricemia. Of these genes and locus, SLC2A9 (46), SLC22A12 (46), and BRAP (46) were previously shown to be related to serum uric acid level; and rs12229654 at 12q24.1 (64), ACAD10 (63), and HECTD4 (63) to lipid profiles. HERPUD2 or CCDC63 has not been shown to be associated with hyperuricemia, gout, or serum uric acid level 
Table XIV. Relationship of genes, chromosomal locus, and SNPs associated with metabolic syndrome in the present study to previously reported metabolic disease-related phenotypes.

\begin{tabular}{|c|c|c|c|c|}
\hline Gene/chr. locus & SNP & Chr. & Position & Previously reported phenotypes \\
\hline$H L A-D Q B 2$ & rs200716952 & 6 & 32758997 & $\begin{array}{l}\text { Type } 1 \text { diabetes }(17554300,17632545) \text {, } \\
\text { total cholesterol }(20686565)\end{array}$ \\
\hline $8 \mathrm{p} 21.3$ & rs17482753 & 8 & 19975135 & $\begin{array}{l}\text { Triglycerides }(20686565,23063622,19060906, \\
18193043,21943158,18179892,19913121,17463246), \\
\text { HDL-cholesterol }(20686565,23063622,19060906, \\
21943158,20031538,20370913,20339536,19913121)\end{array}$ \\
\hline CCDC6 & rs1053266 & 10 & 59792934 & Serum urate (23263486) \\
\hline OR52E4 & rs11823828 & 11 & 5884973 & None \\
\hline APOA5 & rs2075291 & 11 & 116790676 & $\begin{array}{l}\text { Triglycerides }(20686565,23063622,22629316,19060906, \\
21943158,19913121,18193043,19802338,23505323, \\
23236364,21386085,19197348), \text { HDL-cholesterol } \\
(23063622,22629316,20686565,21386085,19913121, \\
23236364), \text { LDL-cholesterol }(20686565,19913121), \text { total } \\
\text { cholesterol }(20686565,23063622,20339536,18179892)\end{array}$ \\
\hline OR4F6 & rs 141569282 & 15 & 101806068 & None \\
\hline
\end{tabular}

Data were obtained from Genome-wide repository of associations between SNPs and phenotypes (GRASP) search database (https://grasp. nhlbi.nih.gov/Search.aspx) with a P-value of $<1.0 \times 10^{-6}$. Numbers in parentheses are PubMed IDs. SNP, single nucleotide polymorphism; Chr., chromosome.

Table XV. Relationship of genes, chromosomal locus, and SNPs associated with hyperuricemia in the present study to previously reported metabolic disease-related phenotypes.

\begin{tabular}{|c|c|c|c|c|}
\hline Gene/chr. locus & SNP & Chr. & Position & Previously reported phenotypes \\
\hline SLC2A9 & rs3775948 & 4 & 9993558 & Serum urate (23263486) \\
\hline HERPUD2 & rs2305335 & 7 & 35638368 & None \\
\hline SLC22A12 & rs121907892 & 11 & 64593747 & $\begin{array}{l}\text { Serum urate }(20139978,23263486 \text {, } \\
21768215,20884846,19503597)\end{array}$ \\
\hline \multirow[t]{2}{*}{ CCDC63 } & rs10849915 & 12 & 110895818 & None \\
\hline & rs 10774610 & 12 & 110902439 & None \\
\hline $12 \mathrm{q} 24.1$ & rs12229654 & 12 & 110976657 & HDL-cholesterol (21909109) \\
\hline$B R A P$ & rs3782886 & 12 & 111672685 & Serum urate (23263486) \\
\hline$A C A D 10$ & rs11066015 & 12 & 111730205 & $\begin{array}{l}\text { LDL-cholesterol (20686565), } \\
\text { type } 1 \text { diabetes }(17554300)\end{array}$ \\
\hline HECTD4 & rs11066280 & 12 & 112379979 & $\begin{array}{l}\text { HDL-cholesterol }(21572416,21909109, \\
22751097), \text { LDL-cholesterol }(21572416, \\
20686565) \text {, fasting blood glucose }(23575436)\end{array}$ \\
\hline
\end{tabular}

Data were obtained from Genome-wide repository of associations between SNPs and phenotypes (GRASP) search database (https://grasp. nhlbi.nih.gov/Search.aspx) with a P-value of $<1.0 \times 10^{-6}$. Numbers in parentheses are PubMed IDs. SNP, single nucleotide polymorphism; Chr., chromosome.

in the previous GWASs. A SNP rs2305335 of HERPUD2 was significantly related to the serum uric acid level, whereas two SNPs of CCDC63 were not related to this parameter. Therefore $C C D C 63$ was removed from new loci. We have thus newly identified HERPUD2 as a susceptibility locus for hyperuricemia. The minor $A$ allele of rs2305335 in HERPUD2 was significantly related to increased serum uric acid. Examination of this trait and logistic regression analysis indicate that the
$A$ allele of rs2305335 in HERPUD2 represents a risk factor or hyperuricemia. Furthermore, $O R 4 F 6$ was significantly associated with both T2DM and MetS. We thus newly identified four genes (ZNF860, OR4F6, OR52E4, HERPUD2) that confer susceptibility to early-onset T2DM, MetS, or hyperuricemia.

We previously showed that four, five, or three SNPs were related to T2DM $\left(\mathrm{P}<1.44 \times 10^{-4}\right)$, MetS $(\mathrm{P}<0.05)$, or hyperuricemia $(\mathrm{P}<0.05)$ determined by multivariable logistic regression 
analysis with adjustment for age and sex after the initial EWAS screening of allele frequencies in both early-onset and late-onset individuals with these conditions (54-56). The relationship of two of four SNPs $\left[\mathrm{rs} 138313632\left(\mathrm{P}=1.11 \times 10^{-7}\right)\right.$, rs139012426 $\left.\left(\mathrm{P}=4.29 \times 10^{-5}\right)\right]$ to $\mathrm{T} 2 \mathrm{DM}$ were replicated $(\mathrm{P}<0.05)$ in the present study. The relationship of two of five SNPs [rs1007732 $\left.(\mathrm{P}=0.0405), \mathrm{rs} 7350481\left(\mathrm{P}=3.17 \times 10^{-5}\right)\right]$ to MetS were replicated in the present study. The relationship of two of three SNPs [rs115445569 (P=0.0205), rs60854092 $(\mathrm{P}=0.0490)]$ to hyperuricemia were replicated in the present study. These results suggest that genetic variants associated with T2DM, MetS, or hyperuricemia differ, in part, between early-onset and late-onset individuals with these conditions.

There are several limitations to our study: i) Given that the results were not replicated, their validation will be necessary in independent study populations or in other ethnic groups. ii) It is possible that SNPs identified in the present study are in LD with other genetic variants in the same gene or in other nearby genes that are actually responsible for the development of T2DM, MetS, or hyperuricemia. iii) The functional relevance of identified SNPs to the pathogenesis of T2DM, MetS, or hyperuricemia remains to be elucidated.

In conclusion, we have newly identified four genes (ZNF860, OR4F6, OR52E4, HERPUD2) that confer susceptibility to early-onset T2DM, MetS, or hyperuricemia. Determination of genotypes for the SNPs in these genes may prove informative for assessment of the genetic risk for T2DM, MetS, or hyperuricemia in Japanese.

\section{Acknowledgements}

Not applicable.

\section{Funding}

This study was supported by CREST (JPMJCR1302), Japan Science and Technology Agency (to Y Yamada, JS and IT).

\section{Availability of data and materials}

All data underlying the findings described in the article are available upon request from the corresponding author.

\section{Authors' contributions}

YYam contributed to conception and design of the study; to acquisition, analysis, and interpretation of the data; and to drafting of the manuscript. $\mathrm{KK}, \mathrm{MO}, \mathrm{HH}$ and $\mathrm{TF}$ each contributed to acquisition of the data and to revision of the manuscript. YYas, IT and JS contributed to analysis and interpretation of the data as well as to revision of the manuscript.

\section{Ethics approval and consent to participate}

The study protocol complied with the Declaration of Helsinki and was approved by the Committees on the Ethics of Human Research of Mie University Graduate School of Medicine, Hirosaki University Graduate School of Medicine, and participating hospitals (Gifu Prefectural Tajimi Hospital, Gifu Prefectural General Medical Center, Japanese Red Cross Nagoya
First Hospital, Northern Mie Medical Center Inabe General Hospital, and Hirosaki Stroke and Rehabilitation Center). Written informed consent was obtained from all subjects.

\section{Consent for publication}

All authors approved submission of the final version of the article for publication.

\section{Competing interests}

The authors declare that they have no competing interests.

\section{References}

1. Kharroubi AT and Darwish HM: Diabetes mellitus: The epidemic of the century. World J Diabetes 6: 850-867, 2015.

2. Expert Committee on the Diagnosis and Classification of Diabetes Mellitus: Report of the expert committee on the diagnosis and classification of diabetes mellitus. Diabetes Care 26 (Suppl 1): S5-S20, 2003.

3. Ismail-Beigi F: Clinical practice. Glycemic management of type 2 diabetes mellitus. N Engl J Med 366: 1319-1327, 2012.

4. Emerging Risk Factors Collaboration1, Sarwar N, Gao P, Seshasai SR, Gobin R, Kaptoge S, Di Angelantonio E, Ingelsson E, Lawlor DA, Selvin E, et al: Diabetes mellitus, fasting blood glucose concentration, and risk of vascular disease: A collaborative meta-analysis of 102 prospective studies. Lancet 375: 2215-2222, 2010.

5. Stumvoll M, Goldstein BJ and van Haeften TW: Type 2 diabetes: Principles of pathogenesis and therapy. Lancet 365: 1333-1346, 2005.

6. Almgren P, Lehtovirta M, Isomaa B, Sarelin L, Taskinen MR, Lyssenko V, Tuomi T and Groop L; Botnia Study Group: Heritability and familiality of type 2 diabetes and related quantitative traits in the Botnia Study. Diabetologia 54: 2811-2819, 2011.

7. Prasad RB and Groop L: Genetics of type 2 diabetes-pitfalls and possibilities. Genes (Basel) 6: 87-123, 2015.

8. Wellcome Trust Case Control Consortium: Genome-wide association study of 14,000 cases of seven common diseases and 3,000 shared controls. Nature 447: 661-678, 2007.

9. Sladek R, Rocheleau G, Rung J, Dina C, Shen L, Serre D, Boutin P, Vincent D, Belisle A, Hadjadj S, et al: A genome-wide association study identifies novel risk loci for type 2 diabetes. Nature 445: 881-885, 2007.

10. Dupuis J1, Langenberg C, Prokopenko I, Saxena R, Soranzo N, Jackson AU, Wheeler E, Glazer NL, Bouatia-Naji N, Gloyn AL, et al: New genetic loci implicated in fasting glucose homeostasis and their impact on type 2 diabetes risk. Nat Genet 42: 105-116, 2010.

11. Voight BF, Scott LJ, Steinthorsdottir V, Morris AP, Dina C, Welch RP, Zeggini E, Huth C, Aulchenko YS, Thorleifsson G, et al; MAGIC investigators; GIANT Consortium: Twelve type 2 diabetes susceptibility loci identified through large-scale association analysis. Nat Genet 42: 579-589, 2010.

12. Morris AP, Voight BF, Teslovich TM, Ferreira T, Segrè AV, Steinthorsdottir V, Strawbridge RJ, Khan H, Grallert H, Mahajan A, et al; DIAbetes Genetics Replication And Meta-analysis (DIAGRAM) Consortium: Large-scale association analysis provides insights into the genetic architecture and pathophysiology of type 2 diabetes. Nat Genet 44: 981-990, 2012.

13. Scott RA, Lagou V, Welch RP, Wheeler E, Montasser ME, Luan J, Mägi R, Strawbridge RJ, Rehnberg E, Gustafsson S, et al; DIAbetes Genetics Replication and Meta-analysis (DIAGRAM) Consortium: Large-scale association analyses identify new loci influencing glycemic traits and provide insight into the underlying biological pathways. Nat Genet 44: 991-1005, 2012.

14. Ng MC, Shriner D, Chen BH, Li J, Chen WM, Guo X, Liu J, Bielinski SJ, Yanek LR, Nalls MA, et al; FIND Consortium; eMERGE Consortium; DIAGRAM Consortium; MuTHER Consortium; MEta-analysis of type 2 DIabetes in African Americans Consortium: Meta-analysis of genome-wide association studies in African Americans provides insights into the genetic architecture of type 2 diabetes. PLoS Genet 10: e1004517, 2014. 
15. Cho YS, Chen CH,Hu C, Long J, Ong RT, Sim X, Takeuchi F, Wu Y, Go MJ, Yamauchi T, et al; MuTHER Consortium: Meta-analysis of genome-wide association studies identifies eight new loci for type 2 diabetes in east Asians. Nat Genet 44: 67-72, 2011

16. Mahajan A, Go MJ, Zhang W, Below JE, Gaulton KJ, Ferreira T, Horikoshi M, Johnson AD, Ng MC, Prokopenko I, et al; DIAbetes Genetics Replication And Meta-analysis (DIAGRAM) Consortium; Asian Genetic Epidemiology Network Type 2 Diabetes (AGEN-T2D) Consortium; South Asian Type 2 Diabetes (SAT2D) Consortium; Mexican American Type 2 Diabetes (MAT2D) Consortium; Type 2 Diabetes Genetic Exploration by Nex-generation sequencing in muylti-Ethnic Samples (T2D-GENES) Consortium: Genome-wide trans-ancestry meta-analysis provides insight into the genetic architecture of type 2 diabetes susceptibility. Nat Genet 46: 234-244, 2014

17. Zhao W, Rasheed A, Tikkanen E, Lee JJ, Butterworth AS, Howson JMM, Assimes TL, Chowdhury R, Orho-Melander M, Damrauer S et al; CHD Exome ${ }^{+}$Consortium; EPIC-CVD Consortium; EPIC-Interact Consortium; Michigan Biobank: Identification of new susceptibility loci for type 2 diabetes and shared etiological pathways with coronary heart disease. Nat Genet 49: 1450-1457, 2017.

18. Unoki H, Takahashi A, Kawaguchi T, Hara K, Horikoshi M, Andersen G, Ng DP, Holmkvist J, Borch-Johnsen K, Jørgensen T, et al: SNPs in KCNQ1 are associated with susceptibility to type 2 diabetes in East Asian and European populations. Nat Genet 40: 1098-1102, 2008.

19. Yasuda K, Miyake K, Horikawa Y, Hara K, Osawa H, Furuta H, Hirota Y, Mori H, Jonsson A, Sato Y, et al: Variants in KCNQ1 are associated with susceptibility to type 2 diabetes mellitus. Nat Genet 40: 1092-1097, 2008.

20. Yamauchi T, Hara K, Maeda S, Yasuda K, Takahashi A, Horikoshi M, Nakamura M, Fujita H, Grarup N, Cauchi S, et al: A genome-wide association study in the Japanese population identifies susceptibility loci for type 2 diabetes at UBE2E2 and C2CD4A-C2CD4B. Nat Genet 42: 864-868, 2010.

21. Imamura M, Takahashi A, Yamauchi T, Hara K, Yasuda K, Grarup N, Zhao W, Wang X, Huerta-Chagoya A, Hu C, et al: Genome-wide association studies in the Japanese population identify seven novel loci for type 2 diabetes. Nat Commun 7: 10531, 2016.

22. Alberti KG, Eckel RH, Grundy SM, Zimmet PZ, Cleeman JI, Donato KA, Fruchart JC, James WP, Loria CM and Smith SC Jr; International Diabetes Federation Task Force on Epidemiology and Prevention; Hational Heart, Lung, and Blood Institute; American Heart Association; World Heart Federation; International Atherosclerosis Society; International Association for the Study of Obesity: Harmonizing the metabolic syndrome: A joint interim statement of the International Diabetes Federation Task Force on Epidemiology and Prevention; National Heart, Lung, and Blood Institute; American Heart Association; World Heart Federation; International Atherosclerosis Society; and International Association for the Study of Obesity. Circulation 120: 1640-1645, 2009.

23. Grundy SM, Cleeman JI, Daniels SR, Donato KA, Eckel RH, Franklin BA, Gordon DJ, Krauss RM, Savage PJ, Smith SC Jr, et al; American Heart Association; National Heart, Lung, and Blood Institute: Diagnosis and management of the metabolic syndrome: An American Heart Association/National Heart, Lung, and Blood Institute Scientific Statement. Circulation 112: 2735-2752, 2005.

24. Esposito K, Chiodini P, Colao A, Lenzi A and Giugliano D: Metabolic syndrome and risk of cancer: A systematic review and meta-analysis. Diabetes Care 35: 2402-2411, 2012.

25. Abou Ziki MD and Mani A: Metabolic syndrome: Genetic insights into disease pathogenesis. Curr Opin Lipidol 27: 162-171, 2016.

26. Vattikuti S, Guo J and Chow CC: Heritability and genetic correlations explained by common SNPs for metabolic syndrome traits. PLoS Genet 8: e1002637, 2012.

27. Kraja AT, Vaidya D, Pankow JS, Goodarzi MO, Assimes TL, Kullo IJ, Sovio U, Mathias RA, Sun YV, Franceschini N, et al: A bivariate genome-wide approach to metabolic syndrome: STAMPEED consortium. Diabetes 60: 1329-1339, 2011.

28. Kristiansson K, Perola M, Tikkanen E, Kettunen J, Surakka I, Havulinna AS, Stancáková A, Barnes C, Widen E, Kajantie E, et al: Genome-wide screen for metabolic syndrome susceptibility Loci reveals strong lipid gene contribution but no evidence for common genetic basis for clustering of metabolic syndrome traits. Circ Cardiovasc Genet 5: 242-249, 2012.
29. Tekola-Ayele F, Doumatey AP, Shriner D, Bentley AR, Chen G, Zhou J, Fasanmade O, Johnson T, Oli J, Okafor G, et al: Genomewide association study identifies African-ancestry specific variants for metabolic syndrome. Mol Genet Metab 116: 305-313, 2015.

30. Zabaneh D and Balding DJ: A genome-wide association study of the metabolic syndrome in Indian Asian men. PLoS One 5: e11961, 2010.

31. Zhu Y, Zhang D, Zhou D, Li Z, Li Z, Fang L, Yang M, Shan Z, Li H, Chen J, et al: Susceptibility loci for metabolic syndrome and metabolic components identified in Han Chinese: A multi-stage genome-wide association study. J Cell Mol Med 21: 1106-1116, 2017.

32. Eraly SA, Vallon V, Rieg T, Gangoiti JA, Wikoff WR, Siuzdak G, Barshop BA and Nigam SK: Multiple organic anion transporters contribute to net renal excretion of uric acid. Physiol Genomics 33: 180-192, 2008.

33. Choi HK, Mount DB and Reginato AM; American College of Physicians; American Physiological Society: Pathogenesis of gout. Ann Intern Med 143: 499-516, 2005.

34. Feig DI, Kang DH and Johnson RJ: Uric acid and cardiovascular risk. N Engl J Med 359: 1811-1821, 2008.

35. Fini MA, Elias A, Johnson RJ and Wright RM: Contribution of uric acid to cancer risk, recurrence, and mortality. Clin Transl Med 1: 16, 2012

36. Reginato AM, Mount DB, Yang I and Choi HK: The genetics of hyperuricaemia and gout. Nat Rev Rheumatol 8: 610-621, 2012.

37. Merriman TR: An update on the genetic architecture of hyperuricemia and gout. Arthritis Res Ther 17: 98, 2015.

38. Wallace C, Newhouse SJ, Braund P, Zhang F, Tobin M, Falchi M, Ahmadi K, Dobson RJ, Marçano AC, Hajat C, et al: Genome-wide association study identifies genes for biomarkers of cardiovascular disease: Serum urate and dyslipidemia. Am J Hum Genet 82: 139-149, 2008.

39. Dehghan A, Köttgen A, Yang Q, Hwang SJ, Kao WL, Rivadeneira F, Boerwinkle E, Levy D, Hofman A, Astor BC, et al: Association of three genetic loci with uric acid concentration and risk of gout: A genome-wide association study. Lancet 372: 1953-1961, 2008.

40. Vitart V, Rudan I, Hayward C, Gray NK, Floyd J, Palmer CN Knott SA, Kolcic I, Polasek O, Graessler J, et al: SLC2A9 is a newly identified urate transporter influencing serum urate concentration, urate excretion and gout. Nat Genet 40: 437-442, 2008.

41. Döring A, Gieger C, Mehta D, Gohlke H, Prokisch H, Coassin S, Fischer G, Henke K, Klopp N, Kronenberg F, et al: SLC2A9 influences uric acid concentrations with pronounced sex-specific effects. Nat Genet 40: 430-436, 2008.

42. Kolz M, Johnson T, Sanna S, Teumer A, Vitart V, Perola M, Mangino M, Albrecht E, Wallace C, Farrall M, et al; EUROSPAN Consortium; ENGAGE Consortium; PROCARDIS Consortium; KORA Study; WTCCC: Meta-analysis of 28,141 individuals identifies common variants within five new loci that influence uric acid concentrations. PLoS Genet 5: e1000504, 2009.

43. Yang Q, Köttgen A, Dehghan A, Smith AV, Glazer NL, Chen MH, Chasman DI, Aspelund T, Eiriksdottir G, Harris TB, et al: Multiple genetic loci influence serum urate levels and their relationship with gout and cardiovascular disease risk factors. Circ Cardiovasc Genet 3: 523-530, 2010.

44. Tin A, Woodward OM, Kao WH, Liu CT, Lu X, Nalls MA, Shriner D, Semmo M, Akylbekova EL, Wyatt SB, et al; CARe and CHARGE Consortia: Genome-wide association study for serum urate concentrations and gout among African Americans identifies genomic risk loci and a novel URAT1 loss-of-function allele. Hum Mol Genet 20: 4056-4068, 2011.

45. Li C, Li Z, Liu S, Wang C, Han L, Cui L, Zhou J, Zou H, Liu Z, Chen $\mathrm{J}$, et al: Genome-wide association analysis identifies three new risk loci for gout arthritis in Han Chinese. Nat Commun 6: 7041,2015

46. Köttgen A, Albrecht E, Teumer A, Vitart V, Krumsiek J, Hundertmark C, Pistis G, Ruggiero D, O'Seaghdha CM, Haller T, et al; LifeLines Cohort Study; CARDIoGRAM Consortium; DIAGRAM Consortium; ICBP Consortium; MAGIC Consortium: Genome-wide association analyses identify 18 new loci associated with serum urate concentrations. Nat Genet 45: 145-154, 2013.

47. Matsuo H, Yamamoto K, Nakaoka H, Nakayama A, Sakiyama M, Chiba T, Takahashi A, Nakamura T, Nakashima H, Takada Y, et al: Genome-wide association study of clinically defined gout identifies multiple risk loci and its association with clinical subtypes. Ann Rheum Dis 75: 652-659, 2016. 
48. Nakayama A, Nakaoka H, Yamamoto K, Sakiyama M, Shaukat A Toyoda Y, Okada Y, Kamatani Y, Nakamura T, Takada T, et al; Eurogout Consortium; Eurogout Consortium: GWAS of clinically defined gout and subtypes identifies multiple susceptibility loci that include urate transporter genes. Ann Rheum Dis 76: 869-877, 2017.

49. Ng MC, Lee SC, Ko GT, Li JK, So WY, Hashim Y, Barnett AH, Mackay IR, Critchley JA, Cockram CS, et al: Familial early-onset type 2 diabetes in Chinese patients: Obesity and genetics have more significant roles than autoimmunity. Diabetes Care 24: 663-671, 2001.

50. Bueno AC, Sun K, Martins CS, Elias Junior J, Miranda W, Tao C, Foss-Freitas MC, Barbieri MA, Bettiol H, de Castro M, et al: A novel ADIPOQ mutation (p.M40K) impairs assembly of high-molecular-weight adiponectin and is associated with early-onset obesity and metabolic syndrome. J Clin Endocrinol Metab 99: E683-E693, 2014.

51. de Bruin C, Mericq V, Andrew SF, van Duyvenvoorde HA, Verkaik NS, Losekoot M, Porollo A, Garcia H, Kuang Y, Hanson D, et al: An XRCC4 splice mutation associated with severe short stature, gonadal failure, and early-onset metabolic syndrome. J Clin Endocrinol Metab 100: E789-E798, 2015.

52. Zivná M, Hůlková $\mathrm{H}$, Matignon M, Hodanová K, Vylet'al $\mathrm{P}$, Kalbácová M, Baresová V, Sikora J, Blazková $\mathrm{H}$, Zivný J, et al: Dominant renin gene mutations associated with early-onset hyperuricemia, anemia, and chronic kidney failure. Am J Hum Genet 85: 204-213, 2009.

53. Matsuo H, Ichida K, Takada T, Nakayama A, Nakashima H, Nakamura T, Kawamura Y, Takada Y, Yamamoto K, Inoue H, et al: Common dysfunctional variants in ABCG2 are a major cause of early-onset gout. Sci Rep 3: 2014, 2013.

54. Yamada Y, Sakuma J, Takeuchi I, Yasukochi Y, Kato K, Oguri M, Fujimaki T, Horibe H, Muramatsu M, Sawabe M, et al: Identification of five genetic variants as novel determinants of type 2 diabetes mellitus in Japanese by exome-wide association studies. Oncotarget 8: 80492-80505, 2017.

55. Yamada Y, Sakuma J, Takeuchi I, Yasukochi Y, Kato K, Oguri M, Fujimaki T,Horibe H,Muramatsu M, Sawabe M, et al: Identification of rs7350481 at chromosome 11q23.3 as a novel susceptibility locus for metabolic syndrome in Japanese individuals by an exome-wide association study. Oncotarget 8: 39296-39308, 2017.

56. Yamada Y, Sakuma J, Takeuchi I, Yasukochi Y, Kato K, Oguri M, Fujimaki T, Horibe H, Muramatsu M, Sawabe M, et al: Identification of C21orf59 and ATG2A as novel determinants of renal function-related traits in Japanese by exome-wide association studies. Oncotarget 8: 45259-45273, 2017.
57. Yamada Y, Matsui K, Takeuchi I, Oguri M and Fujimaki T: Association of genetic variants with hypertension in a longitudinal population-based genetic epidemiological study. Int J Mol Med 35: 1189-1198, 2015.

58. Kuzuya T, Nakagawa S, Satoh J, Kanazawa Y, Iwamoto Y, Kobayashi M, Nanjo K, Sasaki A, Seino Y, Ito C, et al; Committee of the Japan Diabetes Society on the diagnostic criteria of diabetes mellitus: Report of the Committee on the classification and diagnostic criteria of diabetes mellitus. Diabetes Res Clin Pract 55: 65-85, 2002.

59. World Health Organization and International Diabetes Federation: Definition and diagnosis of diabetes mellitus and intermediate hyperglycemia: Report of a WHO/IDF consultation. World Health Organization, Geneva, Switzerland, pp1-46, 2006.

60. Grove ML, Yu B, Cochran BJ, Haritunians T, Bis JC, Taylor KD, Hansen M, Borecki IB, Cupples LA, Fornage M, et al: Best practices and joint calling of the HumanExome BeadChip: The CHARGE Consortium. PLoS One 8: e68095, 2013.

61. Anderson CA, Pettersson FH, Clarke GM, Cardon LR, Morris AP and Zondervan KT: Data quality control in genetic case-control association studies. Nat Protoc 5: 1564-1573, 2010.

62. Price AL, Patterson NJ, Plenge RM, Weinblatt ME, Shadick NA and Reich D: Principal components analysis corrects for stratification in genome-wide association studies. Nat Genet 38: 904-909, 2006

63. Teslovich TM, Musunuru K, Smith AV, Edmondson AC, Stylianou IM, Koseki M, Pirruccello JP, Ripatti S, Chasman DI, Willer CJ, et al: Biological, clinical and population relevance of 95 loci for blood lipids. Nature 466: 707-713, 2010.

64. Kim YJ, Go MJ, Hu C, Hong CB, Kim YK, Lee JY, Hwang JY, Oh JH, Kim DJ, Kim NH, et al; MAGIC consortium: Large-scale genome-wide association studies in East Asians identify new genetic loci influencing metabolic traits. Nat Genet 43: 990-995, 2011. 